Open Access

\title{
Virtual empathy as digital competence in education 3.0
}

\author{
Rafael García-Pérez ${ }^{1 *}$, Juan-Manuel Santos-Delgado ${ }^{1}$ and Olga Buzón-García ${ }^{2}$
}

\author{
* Correspondence: \\ rafaelgarcia@us.es \\ 'Department of Educational Research \\ Methods and Assessment in the \\ School of Education at the University \\ of Seville, C/Pirotecnia, s/n, CP 41013 \\ Seville, Spain \\ Full list of author information is \\ available at the end of the article
}

\begin{abstract}
The social and interactive dimension has taken on particular relevance with the appearance of new technologies in education, making the capacity for virtual empathy a key competence for promoting learning processes in virtual environments. Therefore, we conducted a study based on a survey with 704 students who were training as teachers, to whom we applied an adaptation of the empathy scale designed by Gorostiaga et al. (Revista de Educación 364, 12-38, 2014). The study shows a valid and reliable measure of virtual empathy. Results indicate that only $10 \%$ of the sample reached a high level of virtual empathy and, for this reason, we believe it should be included in teacher education syllabuses.
\end{abstract}

Keywords: Virtual empathy, Digital competence, Teacher Education, Web 2.0 technologies, Social networks

\section{Introduction}

New literacies in today's digital society have concentrated much scientific-educational attention over the last decade (Area \& Pessoa, 2012; Greene, Yu, \& Copeland, 2014; Meyers, Erikson, \& Small, 2013). The eruption of new technologies increasing the opportunities and contexts of learning have brought to the forefront of educational debate the social function and pedagogical model of educational institutions together with the role and competences of teachers themselves in these new scenarios.

The challenges currently facing education involve incorporating new pedagogical strategies in a more open and flexible formal education as several authors have recently pointed out (Castañeda \& Adell, 2013; Cobo \& Moravec, 2011; Coll \& Engel, 2014; Tyner, Gutiérrez-Martín, \& Torrego-González, 2015).

In this study, we propose studying the level of virtual empathy manifested by trainee teachers as a key digital competence in new pedagogies for Education 3.0 and how this relates to their social presence in virtual environments.

\section{Education 3.0 and new pedagogies}

The European digital agenda underlines the need for a change in the pedagogical model of educational institutions to meet the demands of the new knowledge society, pointing towards a greater flexibility and tailoring of learning which implies giving a greater role to new digital technologies in teaching-learning processes in formal contexts.

(C) 2016 The Author(s). Open Access This article is distributed under the terms of the Creative Commons Attribution 4.0 International License (http://creativecommons.org/licenses/by/4.0/), which permits unrestricted use, distribution, and reproduction in any medium provided you give appropriate credit to the original author(s) and the source, provide a link to the Creative Commons license, and indicate if changes were made. 
Several authors (Hussain, 2012; Poore, 2014) have reflected on the implications of the Web 3.0 for education, suggesting the possibility of accessing information in one global data repository as one of its most characteristic features. Although the web 2.0 meant a revolution due to the degree of interactivity and participation it has involved, it has also led to the generation of a large quantity of unorganized contents. The Web 3.0 means that this information may be systematized intelligently, opening up the possibility for its use and conversion into useful knowledge (Ramírez-Leon \& Peña-Alcira, 2011). One of the great contributions of the Web 3.0 is the ubiquitous access to learning resources through mobile devices, which enable access to any content, at any time and virtually anywhere.

In his reflection on online pedagogy, Weller (2009) highlights that features of the Web 3.0, such as user-generated content, data generated on an incommensurate scale, the network being sustained on an architecture of participation, have meant that new pedagogies are being explored, or at least interest has been shown towards them.

Several studies (Anderson, 2010; Castañeda \& Adell, 2013; Wheeler, 2015) have looked into online pedagogies, finding that they all share a vision of the learner as an active person who is capable of deciding what, how, when, where and with whom they learn, which is the core of the educational process. They take a wide-ranging and dynamic view of learning as a process covering different contexts of activity, which provide opportunities and resources for learning. All these theories (connectivism, rhizomatic learning, self-regulated learning, etc.) are proposed as a response to the need to re-think education as a more open and flexible formal education.

\section{The digital competences of teachers}

One of the key factors for educational innovation and improvement is the training of teachers in ICT as highlighted by a number of international reports (OCDE, 2014). The EU's DIGCOMP project (Ferrari, 2013) establishes five areas of digital competence, amongst which it identifies the ability to communicate in digital settings, collaborate with other people and share resources using online tools. In turn, Area and Pessoa (2012) also identify five areas of competence, amongst which they do not just contemplate skills to express oneself through different languages and be able to communicate and collaborate with other people using technologies, but also include skills of expression and emotional regulation regarding ICTs as a crucial facet. Janssen et al. (2013) also identify several areas of digital competence, including the capacity to collaborate and communicate mediated by technology and learn about and with technologies to improve self-efficacy and decision-making. All these studies agree that one of the most important skills in these new settings is linked to protection and security on the net.

Some recent research has looked into the digital competence of teachers. In their study with non-university teachers, Cortina-Pérez, Gallardo-Vigil, Jiménez-Jiménez, and Trujillo-Torres (2014) found that more than $60 \%$ of teachers made no use of Web 2.0 tools in their teaching work and, despite over $90 \%$ of them having received ICT training, more than $70 \%$ felt they were not prepared to make educational use of these technologies. In a recent study, again with non-university teachers, García-Pérez, Rebollo-Catalán, and García-Pérez (2016) showed that they have a moderate level of digital competence in the use of virtual social networks, but their digital competence for teaching is less developed. 
This assessment is also repeated at university level, where San Nicolás, Fariña, and Area (2012) also found that, although lecturers have adequate ICT proficiency, they hardly use the Web 2.0 (social networks, debating forums and blogs). Marcelo, Yot, and Mayor (2015) obtained very similar results in the use university teachers make of the social networks as a means of teaching-learning, finding that they hardly ever use these media to distribute news, information and the latest developments.

However, although all these studies present global results about teachers' digital competences, few look specifically into emotional skills and even fewer into empathy in this area.

\section{Virtual empathy as a digital competence}

Empathy has been studied before in education, and there is a whole body of knowledge about the effects of empathy on educational processes. The most recent research about teacher effectiveness shows that empathic teachers do not just tend to create more secure and motivating environments and establish positive relations with their students, but also their empathy has positive effects on student performance (Goroshit \& Hen, 2014).

Fernández-Pinto, López-Pérez, and Márquez (2008) argue that empathy needs to be seen as a multidimensional skill involving cognitive, emotional and situational aspects. In a previous study, Martínez-Otero Pérez (2011) found gender differences in the balanced presence of the affective (empathic stress and empathic joy) and cognitive dimension (adoption of perspective and emotional understanding) of empathy in trainee teachers. The study found that men find it easier to recognize and understand other people's emotional states rather than involve themselves in other's affective situations; meanwhile women demonstrate the ability to share emotions besides identifying and understanding other people's state of mind.

In turn, research into digital literacy (Eshet-Alkalai, 2004; Ala-Mutka, 2011; Area \& Pessoa, 2012) has demonstrated the importance of including emotional skills in the study of digital competence. Ala-Mutka (2010, 2011) considers the emotional dimension as one of the key factors on the conceptual map of digital competence for the 21st Century, including it as part of intercultural communication and collaboration made possible by new virtual spaces for informal learning on social networks. Eshet-Alkalai (2004) also includes the socio-emotional dimension among the components of digital literacy, pointing out that this is the most difficult facet to develop because it includes cognitive (empathic understanding) and metacognitive (adoption of the other's perspective) aspects together with affective ones. For that reason, it has been one of the least evaluated aspects, to the extent that we do not have specific tools to measure it.

Some previous studies have analyzed the emotional dimension as a key element of learning in virtual surroundings. Based on the theory of Garrison and Anderson (2003), which included the affective dimension as a facet of social presence in virtual learning settings, a series of studies have analyzed didactic and social presence in educational processes in virtual surroundings (Marcelo \& Perera, 2007; Santos-Acevedo, 2011; Kim, 2011; Vega-Caro \& Buzón-García, 2016). They focused particularly on the expression of positive emotions, which strengthen affective bonds in a learning community. We also found studies analyzing the quality of relations and the cohesion of virtual communities, including affective aspects (Rebollo-Catalán, García-Pérez, \& Sánchez-Franco, 2013). 
However, we find that while empathy is a skill, which has been widely studied in education, it has not been featured specifically in the study of educational processes created by new virtual environments. For that reason, this study intends to analyze the empathy shown by trainee teachers in open virtual surroundings, which foster informal learning by adapting a measure, which has proved effective in the study of empathy in face-to-face education.

In their review of measures of empathy, López-Pérez, Fernández-Pinto, and Abad (2008) maintain that Cognitive and Affective Empathy Scale (CAES) is valid and reliable for measuring empathy because of the amount of knowledge tested on previous studies about its structure and intercultural meaning. Drawing on the previous study of Gorostiaga, Balluerka, and Soroa (2014) in which they adapted and validated this measure, a secondary, but no less important, objective of our study was to adapt and validate the CAES for measuring empathy in open virtual environments, which favor learning.

\section{Method}

We conducted a descriptive study based on self-report measures, comparing groups ccording to gender, university degrees, cohort and performance. In this study, we adopted an ex post facto design to explore the nature and behavior of the measure of virtual empathy in the analyzed sample. To complement this, we applied measures to validate the construct and criterion of the virtual empathy measure and reduce bias stemming from the self-report measures.

\section{Participants}

The sample consisted of 704 students at the University of Seville, who were being trained to be teachers in primary or secondary education, or vocational training. They were selected using stratified sampling by quotas, considering type of preservice teacher education and the year of study. Table 1 presents the sociodemographic data of the sample.

\section{Instruments and procedure}

To measure virtual empathy we applied an adapted scale of the CAES (López-Pérez et al., 2008; Gorostiaga et al., 2014) consisting of 33 items measuring the adoption of perspective, emotional understanding, empathic stress and empathic joy, with responses being recorded on a Likert scale ranging from 1 (totally disagree), 2 (disagree), 3 (agree) and 4 (totally agree). We applied a CATPCA analysis using an optimal scaling procedure for ordinal data, obtaining a measure which was reliable $(\alpha=.90)$ and valid (with correlation rates over 30 for the items in the main component). Each of the scale's dimension was also reliable (adoption of perspectives $=.79$; emotional comprehension $=.73$; empathic stress $=.74$; and empathic joy $=.80)$.

In addition, we applied two scales for measuring criterion validity. On the one hand, we used the social presence scale which has proved valid in previous studies (Vega Caro, 2013; Vega-Caro \& Buzón-García, 2016), and in this study we obtained a value of Rho $=.311(p \leq .01)$. We also applied a scale to measure relational quality in virtual environments (Rebollo-Catalán et al., 2013), which correlated with the measure of virtual empathy in this study $(\mathrm{Rho}=.435 ; p \leq .01)$. 
Table 1 Socio-demographic data of the sample

\begin{tabular}{llll}
\hline Variables & Categories & Frequencies & Percentage \\
\hline Gender & Male & 143 & $20.3 \%$ \\
Age & Female & 561 & $79.7 \%$ \\
& $\leq 20$ years & 219 & $32 \%$ \\
& 21 to 25 years & 364 & $53.1 \%$ \\
Type of preservice teacher education & $\geq 26$ years & 102 & $14.9 \%$ \\
& Direct (Education) & 331 & $47 \%$ \\
University degree & Indirect (Others) & 373 & $53 \%$ \\
& Education & 331 & $47 \%$ \\
& Socioeconomic & 193 & $27.4 \%$ \\
Year & Health-psychology & 77 & $10.9 \%$ \\
& Experimental Sciences & 103 & $14.6 \%$ \\
& First & 273 & $38.8 \%$ \\
& Second & 132 & $18.8 \%$ \\
Residence & Third & 247 & $35.1 \%$ \\
& Fourth & 52 & $7.3 \%$ \\
& Low $(\leq 6$ p.) & 76 & $15.3 \%$ \\
& Mid $(>6$ p. y $<8 p)$. & 312 & $62.7 \%$ \\
& High $(>8$ p.) & 110 & $22.1 \%$ \\
& Urban & 314 & $44.7 \%$ \\
& Rural & 389 & $55.3 \%$ \\
\hline
\end{tabular}

Source: Own elaboration

To reduce the bias arising from the use of self-report measures, we applied the social desirability scale (Ferrando \& Chico, 2000), with no correlation being found with virtual empathy (Rho $=.133 ; p \leq .01)$, thereby demonstrating that responses were not biased by social desirability.

The questionnaires were completed in university lecture rooms during classes at a time previously arranged with the lecturers and it took participants roughly half an hour to fill them in. Students were informed of the voluntary and anonymous nature of their participation in the study and they were told about its objectives.

Data was analyzed using the SPSS statistical package (version 20 for Windows). Once the unidimensionality of the virtual empathy scale had been checked, we created a variable from the sum of all the items, with the overall variable of virtual empathy ending up on a scale of 33 to 132 points. For this study, we have presented the results of overall virtual empathy on a four-point scale (Deficient $=33-66$; Basic $=67-82$; Median $=$ 83-98; Optimal =99-132), after checking that this recoding had not affected its validity and reliability.

We performed an exploratory analysis of the variables to find out their structure and distribution. After applying the Kolmogorov Smirnov test, we applied the non-parametric contrast tests, Mann-Whitney's $U$ and Kruskal-Wallis's Anova for independent samples to study whether there were statistically significant differences according to gender, cohort and performance and we applied Cohen's $d$ for size effect. 


\section{Results}

To identify the level of virtual empathy of the trainee teachers, we obtained a mean of 86.8 with a standard deviation of 9.8 , corresponding to a medium level of empathy. Thus, we found that $3.1 \%$ of teachers showed a very deficient level of empathy, $25.6 \%$ a minimum level, $61.2 \%$ a medium level and $10.1 \%$ a maximum degree of empathy (Fig. 1).

As for the dimensions of virtual empathy that trainee teachers develop more favorably, empathic joy obtained the highest value (2.90) on a scale of 1 to 4 , while the lowest mean was obtained by empathic stress with a value of 2.42 (Fig. 2).

From the overall set of indicators of virtual empathy, which we explored in this study, trainee teachers obtained high scores in fourteen of them, with scores indicating a positive position on the Likert scale (a value of 2 meaning a negative score, 3 a positive one). These items are the ones, which best express the virtual empathy of trainee teachers (Table 2).

As one can see, we found indicators of the four dimensions of empathy, such as feeling joy about the success of colleagues on the network (item 4: empathic joy), realizing the intentions of other people on the network (item 1: empathic understanding), feeling sad because of the problems affecting other people on the social network (item 5: empathic stress), putting oneself in the position of other people on the social network (item 26r: adoption of perspective). However, it is noteworthy that of these fourteen items with the highest mean score, $50 \%$ of them came from the dimension of empathic joy (7/14). In fact, all the indicators of this dimension were in this high scoring group. There was also a preponderance of indicators of the empathic understanding dimension (5/14); while the dimensions of empathic stress (1/14) and adoption of perspective (1/14) were represented by just one item each.

In contrast, scale items 23 and 6 obtained the lowest mean scores, which covered, on the one hand, empathic stress about the expression of sadness because of other people's problems $(\mathrm{M}=1.83$; $\mathrm{SD}=.776)$ and, the other, adoption of perspective which implies to taking into account other people's opinions for decision-making $(M=1.98$; $S D=.856)$.

To verify the hypothesis of differences according to gender, type of preservice teacher education, cohort and performance, we applied non-parametric techniques (Mann Whitney $U$ ranking test) because the distribution did not produce a normal curve (KolmogorovSmirnov Test $\left.{ }_{n} ; \mathrm{Z}=1.738 ; p=.005\right)$.

Differences were observed in the levels of "virtual empathy" according to gender ( women $=87.7$; s.d. $=9.6$ vs. men $=83.1$; s.d. $=9.8)$ in favor of women $\left(U_{M-W}=24888.0\right.$; $p=.000$ ). The size effect introduced by the gender variable (Cohen's $\mathrm{d}=.47 ; r=.23$ ) can be seen as moderate but significant.

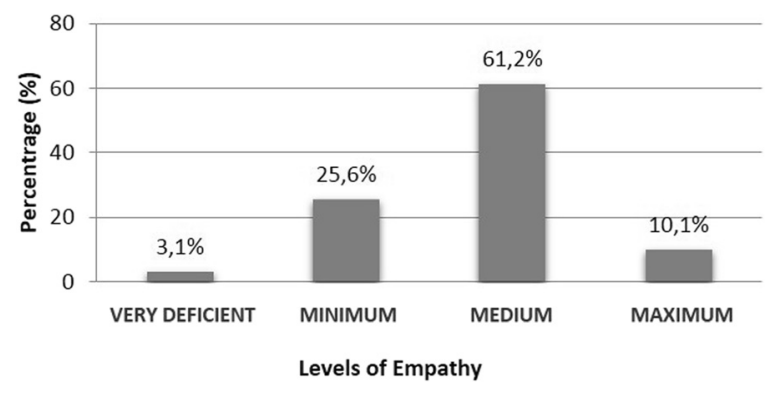

Fig. 1 Degree of Virtual Empathy of Trainee Teachers 


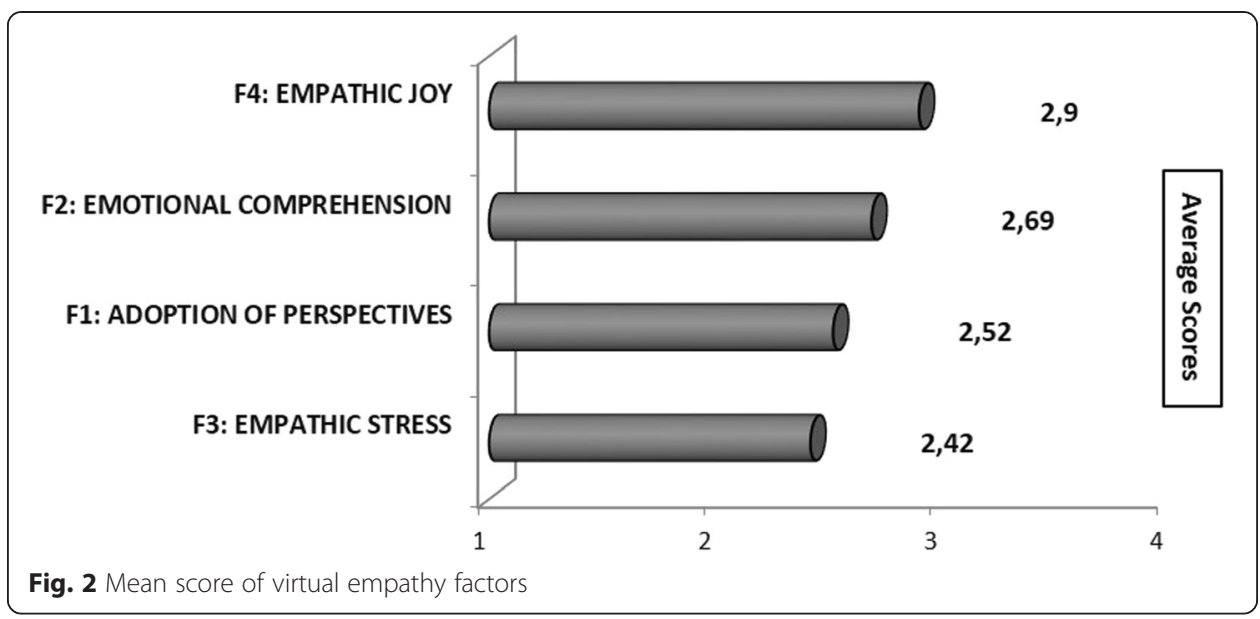

Also significant $\left(\mathrm{U}_{\mathrm{M}-\mathrm{W}}=42152.0 ; p=.000\right)$ were the differences between participants being trained expressly for teaching (studying education sciences) and those studying a degree in other sciences (education sciences $=88.6$; s.d. $=9.2$ vs. Other sciences $=85.1$; s.d. $=10.0)$ which also have professional outlets in education. In this case, the effect (Cohen's $\mathrm{d}=.36 ; r=.18$ ) was also moderate.

We found very small effects (Cohen's $\mathrm{d}=.22 ; r=.11$ ) regarding differences between cohorts $\left(\mathrm{U}_{\mathrm{M}-\mathrm{W}}=45905.5 ; p=.008\right)$ in favor of lower years as opposed to higher ones (years 1 and $2=87.7$; s.d. $=9.4$ vs. years 3 or higher $=85.5$; s.d. $=10.1$ ).

Table 2 Description of some of the indicators of virtual empathy on the social networks

\begin{tabular}{|c|c|c|}
\hline Items $^{a}$ & Mean & Sd. \\
\hline $\begin{array}{l}\text { 4. It makes me happy if a friend from my social network has achieved something, } \\
\text { been successful or won a prize }\end{array}$ & 3.10 & .676 \\
\hline $\begin{array}{l}\text { 1. I quickly realize the intentions of members of my network when they are taking part } \\
\text { (because of their messages, tone of language...) }\end{array}$ & 3.04 & .602 \\
\hline 16. It makes me happy if something good happens to someone on my social network & 2.97 & .685 \\
\hline 22. When I see that someone in my social network has got a job, I feel pleased for them & 2.96 & .674 \\
\hline 2. I feel good when I see that members of my social network are enjoying themselves & 2.89 & .612 \\
\hline $\begin{array}{l}\text { 5. It makes me sad if someone from my social network shares that they have had an } \\
\text { accident or have a serious problem }\end{array}$ & 2.89 & .751 \\
\hline $\begin{array}{l}7 \mathrm{r} \text {. I hardly ever realize how someone close to me on my social network is feeling by just } \\
\text { seeing how he or she participates }\end{array}$ & 2.87 & .736 \\
\hline 14r. I hardly ever realize, through the social network, when someone is not feeling OK & 2.86 & .751 \\
\hline 13. I soon realize when someone close to me on my social network is in a bad mood & 2.84 & .767 \\
\hline $\begin{array}{l}\text { 9. It makes me happy when a new friend who has just connected to my social network } \\
\text { feels good amongst us }\end{array}$ & 2.81 & .712 \\
\hline I I feel good when I see that other people on my social network are happy & 2.81 & .714 \\
\hline $\begin{array}{l}\text { 30r. I think I am a cold person with few feelings on the social network, because I don't } \\
\text { get emotional that easily }\end{array}$ & 2.80 & .897 \\
\hline r. It makes me happy when someone on the social network says that they have been lucky & 2.80 & .755 \\
\hline $\begin{array}{l}\text { r. I find it difficult to put myself in someone else's position on my social network, to see } \\
\text { ings as they do }\end{array}$ & 2.76 & .707 \\
\hline
\end{tabular}

The negative items have been recoded inversely to express the direct score of empathy Source: Own elaboration 
Finally, we applied the Kruskal-Wallis ANOVA to demonstrate significant differences $\left(\mathrm{Chi}^{2}=6.542 ; p=.038\right)$ in favor of the group with the highest marks $(>8 \mathrm{p}$.) in the previous year $(\mathrm{m}=87.1$; sd. $=9.9)$ against the group with the lowest marks $(\leq 6 \mathrm{p}).(\mathrm{m}=83.2$; s.d. $=$ 9.4). The size effect of the variable on level of virtual empathy was also moderate, but slightly higher in this case (Cohen's $\mathrm{d}=.40 ; r=.20$ ).

There were no significant differences depending on whether participants lived in rural or urban areas $\left(\mathrm{U}_{\mathrm{M}-\mathrm{W}}=50905.5 ; p=.417\right)$.

\section{Discussion and conclusions}

The results from this study indicate that trainee teachers have a moderate level of virtual empathy, with empathic stress and the adoption of perspectives being the dimensions, which obtained the lowest scores while empathic joy and understanding were the most developed.

Only $10.1 \%$ of teachers showed an optimal level of empathy on the social networks. The very nature of the interactions, which take place on social networks and the reasons for using them, may explain these results (Jiménez-Cortés, Rebollo-Catalán, García-Pérez, \& Buzón-García, 2015).

The study also found interesting differences in the virtual empathy of teachers depending on gender and type of preservice teacher education. Students who were being trained exclusively to become teachers demonstrated more empathy than those training to become teachers indirectly while taking other degrees. A more in-depth study of syllabuses of these degrees may be required to analyze the reasons for this difference. However, the study of differences between cohorts indicates greater virtual empathy amongst younger students (lower years) compared to their older colleagues in higher years. This may be due to the effects of age on digital skills as has been documented in previous studies (Rebollo-Catalán et al., 2013).

We also found differences in virtual empathy regarding gender in favour of women, which ties in with previous studies, which have analyzed empathy in face-to-face education (Martínez-Otero Pérez, 2011). It would be interesting to find out more about these differences in future studies by considering the scores in different dimensions of empathy.

These results allow us to conclude that empathic stress and the adoption of perspectives are the aspects with the greatest deficits in teacher training. These are two dimensions, which are particularly important for the creation of safe and motivating environments and the establishment of positive relations (Goroshit \& Hen, 2014).

In parallel, the study presents a valid and reliable measure of virtual empathy, which contemplates cognitive and affective dimensions involved in its development via social networks, on the same lines as previous studies, which have emphasized face-to-face empathy as a multidimensional skill (Fernández-Pinto et al., 2008; Gorostiaga et al., 2014).

\footnotetext{
Authors' information

García-Pérez, Rafael

Tenured professor in the Department of Educational Research Methods and Diagnostics in the School of Education at the University of Seville (Spain). His main research area is focused on assessment of educational processes in virtual environments. Now he is carrying out a research project about the affective relationship quality and empathy as virtual skills and as an explanatory factor of the digital inclusion in social networks.

Santos Delgado, Juan Manuel

PhD student in Doctorate Schools of Education at the University of Seville (Spain), which develops his doctoral thesis about virtual affective relationship quality and empathy as digital competence in education 3.0. This article represents the first contribution in the doctoral thesis.

Buzón-García, Olga
} 
Aggregated Professor in Department of ITC in the School of Education at the International University of La Rioja (UNIR). Her main research area is focused on E-learning and ICT in Higher Education European Area and in assessment of educational processes in virtual environments.

\section{Author details}

Department of Educational Research Methods and Assessment in the School of Education at the University of Seville, C) Pirotecnia, s/n, CP 41013 Seville, Spain. ${ }^{2}$ International University of La Rioja (UNIR), Gran Vía Rey Juan Carlos I, 41, 26002 Logroño, Spain.

Received: 1 December 2015 Accepted: 11 May 2016

Published online: 06 July 2016

\section{References}

Ala-Mutka, K. (2010). Learning in Informal Online Networks and Communities. Institute for Prospective. Technological Studies, Joint Research Centre, European Commission. Retrieved from http://ftp.jrc.es/EURdoc/JRC56310.pdf

Ala-Mutka, Kirsti (2011). Mapping Digital Competence: Towards a Conceptual Understanding. Institute for Prospective Technological Studies. Retrieved from: http://ftp.jrc.es/EURdoc/JRC67075_TN.pdf

Anderson, T. (2010). Theories for learning with emerging technologies. In G. Valesianos (Ed.), Emerging technologies in distance education (pp. 23-40). Edmonton, Canada: AU Press, Athabasca University.

Area, M., \& Pessoa, T. (2012). From solid to liquid: new literacies to the cultural changes of Web 2.0. Comunicar, 38(19), 13-20. doi:10.3916/C38-2012-02-01

Castañeda, L., \& Adell, J. (Eds.). (2013). Entornos Personales de Aprendizaje: claves para el ecosistema educativo en red. Alcoy: Marfil.

Cobo, C., \& Moravec, J. W. (2011). Aprendizaje invisible. Hacia una nueva ecología de la educación. Barcelona: Collecció Transmedia XXI. Laboratori de Mitjans Interactius/Publicacions i Edicions de la Universitat de Barcelona.

Coll, C., \& Engel, A. (2014). Introduction: Personal Learning Environments in the context of formal education. Culture \& Education, 26(4), 617-630. doi:10.1080/11356405.2014.985947

Cortina-Pérez, B., Gallardo-Vigil, M. A., Jiménez-Jiménez, M. A., \& Trujillo-Torres, J. M. (2014). Digital illiteracy: a challenge for 21st century teachers. Culture \& Education, 26(2), 231-264. doi:10.1080/11356405.2014.935108

Eshet-Alkalai, Y. (2004). Digital Literacy. A Conceptual Framework for Survival Skills in the Digital Era. Journal of Educational. Multimedia \& Hypermedia, 13(1), 93-106. Retrieved from: http://www.openu.ac.il/personal_sites/ download/Digital-literacy2004-JEMH.pdf

Fernández-Pinto, I., López-Pérez, B., \& Márquez, M. (2008). Empathy: measures, theories and applications under review. Annals of Psychology, 24(2), 284-298. Retrieved from: http://www.um.es/analesps/v24/v24_2/12-24_2.pdf

Ferrando, P. J., \& Chico, E. (2000). Adaptación y análisis psicométrico de la escala de deseabilidad social de Marlowe y Crowne. Psicothema, 12(3), 383-389. Retrieved from: http://www.psicothema.com/pdf/346.pdf

Ferrari, A. (2013). DIGCOMP a framework for developing and understanding digital competence in Europe. In Y. Punie \& B. N. Brecko (Eds.). Luxembourg: Publications Office. Retrieved from: http://ipts.jrc.ec.europa.eu/publications/pub. $\mathrm{cfm}$ ?id=6359

García-Pérez, R., Rebollo-Catalán, A., \& García-Pérez, C. (2016). The relationship between teacher training preferences and their digital skills on social networks. Bordon, 68(2), 137-153.

Garrison, D. R., \& Anderson, T. (2003). E-learning in the $21^{\text {st }}$ century: a framework for research and practice. London: Routledge/Falmer.

Goroshit, M., \& Hen, M. (2014). Does Emotional Self-efficacy Predict Teachers' Self-efficacy and Empathy? Journal of Education and Training Studies, 2(3), 26-32. doi:10.11114/jets.v2i3.359

Gorostiaga, A., Balluerka, N., \& Soroa, G. (2014). Assessment of empathy in educational field and its relationship with emotional intelligence. Revista de Educación, 364, 12-38. doi: 10.4438/1988-592X-RE-2014-364-253

Greene, J. A., Yu S. B., \& Copeland, D. Z. (2014). Measuring critical components of digital literacy and their relationships with learning. Computers \& Education, 76, 55-69. doi:10.1016/j.compedu.2014.03.008

Hussain (2012). E-Learning $3.0=$ E-Learning $2.0+$ Web 3.0? IADIS International Conference on Cognition and Exploratory Learning in Digital Age. Retrieved from: http://files.eric.ed.gov/fulltext/ED542649.pdf

Janssen, J., Stoyanov, S., Ferrari, A., Punie, Y., Pannekeet, K., \& Sloep, P. (2013). Experts' views on digital competence: Commonalities and differences. Computers \& Education, 68, 473-481. doi:10.1016/j.compedu.2013.06.008

Jiménez-Cortés, R., Rebollo-Catalán, A., García-Pérez, R., \& Buzón-García, O. (2015). Social networks user motivation: an analysis of rural women's profiles. RELIEVE, 21(1). doi:10.7203/relieve.21.1.5153

Kim, J. (2011). Developing an instrument to measure social presence in distance Higher Education. British Journal of Educational Technology, 42(5), 763-777. doi:10.1111/j.1467-8535.2010.01107.x

López-Pérez, B., Fernández-Pinto, I., \& Abad, F. J. (2008). Test de empatía cognitiva y afectiva, TECA [Cognitive and Affective Empathy Scale - CAES-]. Madrid: TEA.

Marcelo, C., \& Perera, V.H. (2007). Communication and E-learning: Didactic Interaction in New Learning Environments. Revista de Educación, 343, 381-429. Retrieved from: http://www.revistaeducacion.mec.es/re343/re343_17.pdf

Marcelo, C., Yot, C., \& Mayor, C. (2015). University Teaching with Digital Technologies. Comunicar, 45(23), 117-24. doi: 10.3916/C44-2015-12

Martínez-Otero Pérez, V. (2011). The empathy in education: study of a university students sample. Revista Electrónica de Psicología Iztacala, 14(4), 174-190. Retrieved from: http://www.medigraphic.com/pdfs/epsicologia/epi-2011/ epi114j.pdf

Meyers, E. M., Erikson, I., \& Small, R. V. (2013). Digital literacy and informal learning environments: An introduction. Learning, Media and Technology, 38(4), 355-367. doi:10.1080/17439884.2013.783597

OCDE. (2014). TALIS 2013 Results: An international perspective on teaching and learning, TALIS, OCDE Publishing. doi:10.1787/9789264196261-en 
Poore, M. (2014). The Next G Web. Discernment, meaning-making, and the implications of Web3.0 for education, Technology, Pedagogy and Education, 23(2), 167-180. doi:10.1080/1475939X.2013.802992

Ramírez-Leon, Y. V., \& Peña-Alcira, J. B. (2011). Web 3.0 as a Tool to Support Distance Education. Etic@net, 10. Retrieved from: www.ugr.es/ sevimeco/revistaeticanet/numero10/Articulos/Creditos.htm

Rebollo-Catalán, A., García-Pérez, R., \& Sánchez-Franco, M. (2013). Inclusión digital de las mujeres en las redes sociales. Sevilla: Diputación de Sevilla.

San Nicolás, M. B., Fariña, E., \& Area, M. (2012). Teachers' and students' digital skills during virtual teaching development. The case study of Laguna University. Revista Historia de la Educación Latinoamericana, 14(19), 227-245. Retrieved from: http://revistas.uptc.edu.co/revistas/index.php/historia_educacion_latinamerican/article/view/1993/1988

Santos-Acevedo, G. (2011). Social presence in online discussion forums. Píxel-Bit. Revista de Medios y Educación, 39(1), 17-28. Retrieved from: http://acdc.sav.us.es/pixelbit/images/stories/p39/02.pdf

Tyner, K., Gutiérrez-Martín, A., \& Torrego-González, A. (2015). "Multiliteracy" without walls in the age of convergence. Digital competency and the "culture of making" as incentives for continuing education. Profesorado, 19(2), 42-56. Retrieved from: http://www.ugr.es/ recfpro/rev192ART3.pdf

Vega Caro, L. (2013). Presencia social de las mujeres rurales en las redes sociales. En Rebollo-Catalán, García-Pérez y SánchezFranco (Coords.), Inclusión digital de las mujeres en las redes sociales (pp. 131-149). Sevilla: Diputación de Sevilla.

Vega-Caro, L., \& Buzón-García, O. (2016). Rural women's presence in social networks. Pixel-Bit, 48, 149-167. Retrieved from: http://acdc.sav.us.es/ojs/index.php/pixelbit/article/view/281/13

Weller (2009). Using learning environments as a metaphor for educational change. On the Horizon, 17(3), 181-189. doi:10.1108/10748120910993204

Wheeler, S. (2015). Learning with 'e's: educational theory and practice in the digital age. Wales: Crown House Publishing.

Submit your manuscript to a SpringerOpen ${ }^{\odot}$ journal and benefit from:

- Convenient online submission

- Rigorous peer review

- Immediate publication on acceptance

- Open access: articles freely available online

- High visibility within the field

- Retaining the copyright to your article

Submit your next manuscript at $>$ springeropen.com 